\title{
Molecular surveillance of Plasmodium vivax dhfr and dhps mutations in isolates from Afghanistan
}

Sedigheh Zakeri ${ }^{1 *}$, Mandana Afsharpad ${ }^{1}$, Faezeh Ghasemi ${ }^{1}$, Ahmad Raeisi ${ }^{2}$, Najibullah Safi ${ }^{3}$, Waqar Butt $^{4}$, Hoda Atta ${ }^{5}$, Navid D Djadid ${ }^{1}$

\begin{abstract}
Background: Analysis of dihydrofolate reductase (dhfr) and dihydropteroate synthase (dhps) mutations in Plasmodium vivax wild isolates has been considered to be a valuable molecular approach for mapping resistance to sulphadoxine-pyrimethamine (SP). The present study investigates the frequency of SNPs-haplotypes in the dhfr and dhps genes in P. vivax clinical isolates circulating in two malaria endemic areas in Afghanistan.
\end{abstract}

Methods: $P$. vivax clinical isolates $(n=171)$ were collected in two different malaria endemic regions in north-west (Herat) and east (Nangarhar) Afghanistan in 2008. All collected isolates were analysed for SNP-haplotypes at positions $13,33,57,58,61,117$ and 173 of the pvdhfr and 383 and 553 of the pvdhps genes using PCR-RFLP methods.

Results: All 171 examined isolates were found to carry wild-type amino acids at positions 13, 33, 57, 61 and 173, while 58R and $117 \mathrm{~N}$ mutations were detected among $4.1 \%$ and $12.3 \%$ of Afghan isolates, respectively. Based on the size polymorphism of pvdhfr genes at repeat region, type B was the most prevalent variant among Herat (86\%) and Nangarhar (88.4\%) isolates. Mixed genotype infections (type A/B and A/B/C) were detected in only 2.3\% (2/86) of Herat and 1.2\% (1/86) of Nangarhar isolates, respectively. The combination of pvdhfr and pvdhps haplotypes among all 171 samples demonstrated six distinct haplotypes. The two most prevalent haplotypes among all examined samples were wild-type (86\%) and single mutant haplotype $1_{13} \mathrm{P}_{33} \mathrm{~F}_{57} \mathrm{~S}_{58} \mathrm{~T}_{61} \mathbf{\mathbf { N }} \underline{117}_{173 /} \mathrm{I}_{183} \mathrm{~A}_{553}(6.4 \%)$. Double $\left(\mathrm{I}_{13} \mathrm{P}_{33} \mathrm{~S}_{57} \underline{\mathbf{R}}_{58} \mathrm{~T}_{61} \underline{\mathbf{N}}_{17} \mathrm{I}_{173} / \mathrm{A}_{383} \mathrm{~A}_{553}\right)$ and triple mutant haplotypes $\left(\mathrm{I}_{13} \mathrm{P}_{33} \mathrm{~S}_{57} \underline{\mathbf{R}}_{58} \mathrm{~T}_{61} \underline{\mathbf{N}}_{117} \mathrm{I}_{173} / \underline{\mathbf{G}}_{383} \mathrm{~A}_{553}\right)$ were found in $1.7 \%$ and $1.2 \%$ of Afghan isolates, respectively. This triple mutant haplotype was only detected in isolates from Herat, but in none of the Nangarhar isolates.

Conclusion: The present study shows a limited polymorphism in pvdhfr from Afghan isolates and provides important basic information to establish an epidemiological map of drug-resistant vivax malaria, and updating guidelines for anti-malarial policy in Afghanistan. The continuous usage of SP as first-line anti-malarial drug in Afghanistan might increase the risk of mutations in the dhfr and dhps genes in both $P$. vivax and Plasmodium falciparum isolates, which may lead to a complete SP resistance in the near future in this region. Therefore, continuous surveillance of $P$. vivax and $P$. falciparum molecular markers are needed to monitor the development of resistance to $\mathrm{SP}$ in the region.

\section{Background}

Plasmodium vivax is responsible for approximately 70 80 million cases of malaria worldwide and causes extensive morbidity in Central and South America and Asia [1]. The extension of geographic distribution of $P$. vivax, the emergence of chloroquine (CQ) resistance $[2,3]$ and

\footnotetext{
* Correspondence: zakeris@yahoo.com

${ }^{1}$ Malaria and Vector Research Group (MVRG), Biotechnology Research Center, Institut Pasteur of Iran, Pasteur Avenue, P.O. BOX 1316943551, Tehran, Iran
}

also reported fatal cases [4-6] are important issues in developing control strategies. In fact, increasing morbidity and mortality due to emergence of $P$. vivax resistance to CQ [2-6] results in an urgent need to find alternative treatments for P. vivax infection, including antifolate drugs.

Molecular studies have been shown that point mutations in the genes that encode dihydrofolate reductase (DHFR) and dihydropteroate synthase (DHPS) enzymes (key enzymes in the biosynthesis and recycling 
tetrahydrofolate) confer resistance to sulphadoxine-pyrimethamine (SP) in both Plasmodium falciparum and P. vivax parasites [7-12]. Moreover, the $p v d h f r$ and pvdhps genotypes might be associated with treatment failure in individual vivax malaria patients [13]. Although data on the genotypes of these two genes are available in Thailand, the Indian subcontinent and the Indonesian archipelago, such data are limited in many regions, most notably Central and South America and the Middle East.

Different investigations showed that mutant alleles of $p v d h f r$ gene in areas with a long history of extensive SP use are prevalent; however, wild-type $p v d h f r$ has been found more commonly in areas with limited use of SP $[8,10,13,14]$. So far, over 20 different alleles have been described in pvdhfr [15]. Also, different studies of $P$. vivax parasites in various malaria endemic areas, such as Thailand and India showed that mutations at $p v d h f r$ codons 57, 58, 61, 117 and 173, [8,16] were found to be involved in clinical antifolate resistance $[10,15]$. Four mutations have already been identified in pvdhps gene at codons 382, 383, 442 and $553[15,16]$.

Afghanistan is a country in south-central Asia, where malaria has remained a major public health problem in many of its provinces at altitudes below 2,000 metres with low to high transmission potential. Malaria transmission is seasonal from June to November and the peak for P. vivax is around July, but is in October for $P$. falciparum. According to WHO, Afghanistan has the second highest burden of malaria in the Eastern Mediterranean Region (EMR) and the fourth highest rate worldwide, including outside sub-Saharan Africa [17]. National Malaria Control Programmes initiated in 1950s led to a substantial reduction of transmission in Afghanistan, not only by using DDT, but also by increasing the number of diagnosis of malaria patients and treatment. However, the rate of malaria has increased due to war and the lack of the malaria control programme in this country.

After the invasion of the Soviet Union to Afghanistan, the public health system collapsed, health professionals emigrated and poverty increased. Therefore, this resulted in increasing the rates of malaria than any other disease in Afghanistan due to the lack of the malaria control programme. Before the war, in 1970s, the number of recorded cases of malaria per year varied between 40, 000 and 80,000 (an annual incidence of 2.5- 5 per 1000 people). In 2002, the total malaria burden was estimated by the WHO to be 2.2-3 million cases per year. In 2007, 19 cases of malaria per 1,000 population $(466,239$ total reported cases) were reported; however, the estimated cases by WHO is 1,500,000 [17].

The first detection of $P$. falciparum resistance to chloroquine (CQ) was reported in 1989 and with an increase to 90\%, the Ministry of Public Health, National Malaria Control Programme in Afghanistan, decided in 2004 to revise its treatment policy. Therefore, SP-artesunate in combination has been recommended and being used as the first-line anti-malarial treatment, which in fact gives $100 \%$ cure rate [17]. CQ plus primaquine remains the first choice drug for treatment of $P$. vivax mono-infections and resistance to either CQ or SP has not been recorded yet [17]. Furthermore, P. vivax is sympatric with $P$. falciparum [18] in these areas, but the correct diagnosis of mixed infections based on microscopic examination of blood films is not easy and the clinical symptoms caused by the two species cannot be differentiated. As a result, $P$. vivax populations have often been inadvertently exposed to SP pressure and this may have caused the selection of $P$. vivax SP-resistant isolates.

Molecular markers have been validated as tools for surveillance of resistance; therefore, analysis of $p v d h f r$ and pvdhps mutations in wild isolates has been considered to be a valuable molecular approach for mapping drug resistance and monitoring malaria control measures. This is the first study to investigate the frequency of SNPs-haplotypes in the dhfr and dhps genes in $P$. vivax clinical isolates circulating in two malaria endemic areas in Afghanistan. Thus, the out-coming results may be useful for establishing an epidemiological map of drug-resistant vivax malaria, and also updating guidelines for anti-malarial policy in Afghanistan.

\section{Methods}

Study sites and collection of clinical isolates of $P$. vivax

Blood samples $(n=171)$ were collected from the patients who were infected with $P$. vivax mono-infection, reported to the health facilities located in Herat and Nangarhar provinces in Afghanistan. Herat, a province in the north-west of Afghanistan on the border between Iran and Turkmenistan, has 15 districts with a population of around 1,182,000. Totally, 233 confirmed cases with $P$. falciparum $(\mathrm{n}=3)$ and $P$. vivax $(\mathrm{n}=230)$ were reported from public health facilities in 2008. Nangarhar is located in the east of Afghanistan on border with Pakistan. The province has 21 districts with a population of around 1,089,000. In 2008, 1352 and 28,823 confirmed cases with $P$. falciparum and $P$. vivax were reported from public health facilities, respectively. The risk of malaria transmission in both areas is moderate to high. After obtaining informed consent from adults or the parents or legal guardians of children, $1 \mathrm{ml}$ of blood was collected from vivax malaria patients on admission, from April to September 2008. All P. vivax clinical isolates (Nangarhar $=86$ and Herat $=85$ ) were diagnosed by light microscopic examination of Giemsastained blood smears. This study was approved by the 
Ethical Review Committee of Research in Institut Pasteur of Iran.

\section{Parasite genomic DNA extraction and pvdhfr/pvdps genes amplification}

Parasite DNA was extracted from $250 \mu$ infected whole blood by phenol/phenol-chloroform extraction and ethanol precipitation as described previously [19]. The DNA was dissolved in $30 \mu \mathrm{l}$ TE buffer $(10 \mathrm{mM}$ Tris-HCL, $\mathrm{pH}$ 8.0 and $0.1 \mathrm{mM}$ EDTA). $P$. vivax isolates were genotyped for $d h f r$ and $d h p s$ genes by using previously described PCR-RFLP methods [8,10,20] [Tables 1 and 2].

All amplifications were carried out in a final volume of $25 \mu \mathrm{l}$ including $1 \mu \mathrm{l}$ of template from either genomic DNA or the primary reaction. The primers were used at a final concentration of $250 \mathrm{nM}$ and the reaction mixture contained $10 \mathrm{mM}$ Tris-HCL (pH 8.3), $50 \mathrm{mM} \mathrm{KCl}$, $2 \mathrm{mM} \mathrm{MgCl}_{2}$, each of the four deoxynucleotide triphosphates at a concentration of $125 \mu \mathrm{M}$, and $0.2 \mathrm{U}$ of Taq polymerase (Invitrogen, Carlsbad, CA). The DNA fragments, obtained following PCR amplification or RFLP analysis, were electrophoresed on 2.5\% and 3\% Metaphor agarose gels (Invitrogen, Carlsbad, CA), respectively.

\section{Analysis of pvdhfr gene at repeat region}

The region contains a tandem repeat was amplified using $1 \mu \mathrm{l}$ of primary reaction with the following primers as described previously [10]:
VDFN2F: CGGTGACGACCTACGTGGATGAGTCA AAGT

\section{VDFN2R: TAGCGTCTTGGAAAGCACGACGTT} GATTCT

The cycling conditions for this reaction was $95^{\circ} \mathrm{C}$ for $5 \mathrm{~min}, 25$ cycles of $66^{\circ} \mathrm{C}$ for $2 \mathrm{~min}, 72^{\circ} \mathrm{C}$ for $2 \mathrm{~min}, 94^{\circ} \mathrm{C}$ for $1 \mathrm{~min}$ followed by $66^{\circ} \mathrm{C}$ for $2 \mathrm{~min}$ and $72^{\circ} \mathrm{C}$ for 15 min. The DNA fragments obtained following PCR amplification were analysed following electrophoresis on 3\% Metaphor agarose gels. Three size variant types, A (the largest bp), B (the middle bp) and C (the smallest bp), ranging between 230 and $280 \mathrm{bp}$, were detected in the studied samples.

\section{Results}

Detection of mutations in the pvdhfr and pvdhps genes In this investigation, 171 isolates from Nangarhar and Herat were analysed for SNPs-haplotypes at positions 13, 33, 57, 58, 61, 117 and 173 of the $p v d h f r$ and 383 and 553 of $p v d h p s$ genes and also six $p v d h f r / p v d h p s$ alleles were identified. In $p v d h f r$, polymorphisms at positions 58R and $117 \mathrm{~N}$ were found in $2.3 \%$ and $13.9 \%$ of Nangarhar isolates, respectively. Among Herat isolates, mutations at positions $58 \mathrm{R}$ and $117 \mathrm{~N}$ were found in $2.3 \%$ and $3.5 \%$ of the studied isolates, respectively (Table 3 ).

In total, all 171 examined isolates were found to carry wild-type amino acids at positions $13,33,57,61$ and 173, while $58 \mathrm{R}$ and $117 \mathrm{~N}$ mutations were detected among 4.1\% and $12.3 \%$ examined samples, respectively (Table 3 ).

Table 1 Primers and profiles used for amplification of the pvdhfr and pvdhps genes.

\begin{tabular}{|c|c|c|c|c|c|c|c|c|}
\hline \multirow[t]{2}{*}{ Gene } & \multirow{2}{*}{$\begin{array}{l}\text { Nested-PCR } \\
\text { (position) }\end{array}$} & \multirow[t]{2}{*}{ Primer } & \multirow[t]{2}{*}{ Sequence } & \multicolumn{4}{|c|}{ Temperature ${ }^{\circ} \mathrm{C} /$ time (min) } & \multirow[t]{2}{*}{ Product size $(b p)$} \\
\hline & & & & A & $\mathrm{E}$ & D & $\mathrm{C}$ & \\
\hline & Nest-1 & VDTOF & ATGGAGGACCTTTCAGATGTATTTGACATT & $64\left(2^{\prime}\right)$ & $72\left(2^{\prime}\right)$ & $94\left(1^{\prime}\right)$ & 25 & 1869 \\
\hline & & VDTOR & GGCGGCCATCTCCATGGTTATTITATCGTG & & & & & \\
\hline & Nest-2 & VDF13NF & GACCTTTCAGATGTATTTGACATTTACGGC & $66\left(2^{\prime}\right)$ & $72\left(2^{\prime}\right)$ & $94\left(1^{\prime}\right)$ & 25 & 232 \\
\hline & & VDF13NR & GGTACCTCTCCCTCTTCCACTTTAGCTTCT & & & & & \\
\hline \multirow[t]{6}{*}{ pvdhfr } & $\begin{array}{l}\text { Nest-2 } \\
(57,117)\end{array}$ & VDNF57 & CATGGAAATGCAACTCCGTCGATATGATGT & $66\left(2^{\prime}\right)$ & $72\left(2^{\prime}\right)$ & $94\left(1^{\prime}\right)$ & 25 & 472 \\
\hline & & VDFNR & TCACACGGGTAGGCGCCGTTGATCCTCGTG & & & & & \\
\hline & Nest-2 & VDTOF & ATGGAGGACCTTTCAGATGTATTTGACATT & $66\left(2^{\prime}\right)$ & $72\left(2^{\prime}\right)$ & $94\left(1^{\prime}\right)$ & 25 & 608 \\
\hline & & VDFNR & TCACACGGGTAGGCGCCGTTGATCCTCGTG & & & & & \\
\hline & Nest-1 & VDHPSOF & ATTCCAGAGTATAAGCACAGCACATTTGAG & $58\left(2^{\prime}\right)$ & $72\left(1^{\prime}\right)$ & $94\left(1^{\prime}\right)$ & 21 & 1499 \\
\hline & & VDHPSOR & CTAAGGTTGATGTATCCTTGTGAGCACATC & & & & & \\
\hline \multirow[t]{4}{*}{ pvdhps } & $\begin{array}{l}\text { Nest-2 } \\
(383)\end{array}$ & VDHPSNF & AATGGCAAGTGATGGGGCGAGCGTGATTGA & $50\left(2^{\prime}\right)$ & $72\left(2^{\prime}\right)$ & $94\left(1^{\prime}\right)$ & 25 & 703 \\
\hline & & VDHPSNR & CAGTCTGCACTCCCCGATGGCCGCGCCACC & & & & & \\
\hline & Nest-2 & VDHPS553OF & TTCTCTTTGATGTCGGCCTGGGGTTGGCCA & $68\left(1^{\prime}\right)$ & $72\left(1^{\prime}\right)$ & $94\left(1^{\prime}\right)$ & 30 & 170 \\
\hline & & VDHPSNR & CAGTCTGCACTCCCCGATGGCCGCGCCACC & & & & & \\
\hline
\end{tabular}


Table 2 RFLP protocols used for genotyping pvdhfr and pvdhps genes.

\begin{tabular}{|c|c|c|c|c|c|c|}
\hline Gene & Primers & RFLP Position & Restriction Enzyme & Company & Uncut Product Size (bp) & $\begin{array}{l}\text { Cut Product } \\
\text { Size (bp) }\end{array}$ \\
\hline \multirow{10}{*}{ pvdhfr } & VDF13NFNDF13NR & $113 \mathrm{~L}$ & Hae III & Roche & 232 & $\mathrm{~L}: 200+32$ \\
\hline & & P33L & Cfru2l (Sac II) & Fermentas & 232 & $P: 138+94$ \\
\hline & & $\mathrm{S} 58 \mathrm{R}$ & Alu I & Fermentas & 232 & $\begin{array}{l}\text { S: } 167+40+25 \\
\text { R: } 207+25\end{array}$ \\
\hline & & T61M & Tsp45 I & BioLabs & 232 & $\mathrm{~T}: 200+32$ \\
\hline & VDTOFNDFNR & F57I/L & $X m n I$ & Fermentas & 608 & $F: 166+442$ \\
\hline & & $1173 \mathrm{~L}$ & Ecol30 I (Sty I) & Fermentas & 608 & $\begin{array}{l}\mathrm{L}: 438+97+73 \\
\mathrm{I}: 472+136\end{array}$ \\
\hline & VDNF57NDFNR & F57I/L & BsrG I & BioLabs & 472 & I: $444+28$ \\
\hline & & $\mathrm{S} 117 \mathrm{~N} / \mathrm{T}$ & Pvu II & BioLabs & 472 & S: $258+214$ \\
\hline & & $\mathrm{S} 117 \mathrm{~N} / \mathrm{T}$ & Bsr 1 & Fermentas & 472 & $N: 219+253$ \\
\hline & & $\mathrm{S} 117 \mathrm{~N} / \mathrm{T}$ & BstN I & BioLabs & 472 & $\mathrm{~T}: 257+215$ \\
\hline \multirow{2}{*}{ Pvdhps } & VDHPSNFNDHPSNR & A383G & Msp I (Hpa II) & Fermentas & 703 & G: $655+48$ \\
\hline & VDHPS553OF/NDHPSNR & A553G & $\mathrm{MsCl}$ & Biolabs & 170 & $A: 143+27$ \\
\hline
\end{tabular}

Mixed-genotype infections (58S/R and $117 \mathrm{~S} / \mathrm{N})$ were both detected in $3.5 \%(3 / 86)$ of Nangarhar isolate but, the mixed-genotype infection $(117 \mathrm{~S} / \mathrm{N})$ was only detected in $3.5 \%(3 / 85)$ of Herat isolates (Table 3).

In the case of pvdhps gene, polymorphisms at positions A383G and A553G of dhps were investigated and mutation at $383 \mathrm{G}$ was only detected in $1.2 \%(1 / 85)$ of Herat samples (Table 3). This mutation was also confirmed by sequencing analysis (accession no. Gu549414).

\section{Repeat variation in pvdhfr gene}

In this investigation, all three types (A, B and $\mathrm{C}$ ) were found among Afghan isolates. The frequency distribution for type A, B and C were 5.8\% (5/86), 88.4\% $(76 / 86)$ and $4.6 \%(4 / 86)$ among Nangarhar isolates, respectively. However, for Herat samples, the prevalence of type A, B and C were 9.4\% (8/85), 86\% (73/85) and $2.3 \%(2 / 85)$, respectively. Mixed-genotype infections (type A/B) were detected in only $2.3 \%(2 / 85)$ of Herat and mixed types $(\mathrm{A} / \mathrm{B} / \mathrm{C})$ were detected in $1.2 \%(1 / 86)$ of Nangarhar isolates (Figure 1).

Comparison of pvdhfr and pvdhps haplotypes in Afghan isolates with that in other global geographical areas

The combination of $p v d h f r$ and $p v d h p s$ haplotypes among all 171 samples in this study demonstrated six distinct haplotypes previously reported from various geographic areas (Figure 2 and Additional file 1). The two most prevalent haplotypes among all examined samples were wild-type (86\%) and $\mathrm{I}_{13} \mathrm{P}_{33} \mathrm{~F}_{57} \mathrm{~S}_{58} \mathrm{~T}_{61} \underline{\mathbf{N}}_{117} \mathrm{I}_{173} / \mathrm{A}_{383} \mathrm{~A}_{553}$ (6.4\%). Alleles with two mutations at position $58 \mathrm{R}$ and $117 \mathrm{~N}$ $\left(\mathrm{I}_{13} \mathrm{P}_{33} \mathrm{~F}_{57} \underline{\mathbf{R}}_{58} \mathrm{~T}_{61} \underline{\mathbf{N}}_{117} \mathrm{I}_{173} / \mathrm{A}_{383} \mathrm{~A}_{553}\right)$ accounted for $1.7 \%$ of the total isolates and $\mathrm{I}_{13} \mathrm{P}_{33} \mathrm{~S}_{57} \underline{\mathbf{R}}_{58} \mathrm{~T}_{61} \underline{\mathbf{N}}_{117} \mathrm{I}_{173} /$ $\underline{\mathbf{G}}_{383} \mathrm{~A}_{553}(1.2 \%)$ mutant haplotype was only detected among Herat but in none of the Nangarhar isolates (Figure 2 and Table 3 ). In addition, based on size polymorphism of $p v d h f r$ genes at repeat region, type B was

Table 3 The frequency distribution of SNPs combinations of pvdhfr and pvdhps alleles associated with sulphadoxinepyrimethamine in $P$. vivax isolates from Afghanistan.

\begin{tabular}{|c|c|c|c|c|c|c|c|c|c|c|}
\hline \multicolumn{7}{|c|}{ pvdhfr } & \multicolumn{2}{|c|}{ pvdhps } & \multirow{2}{*}{$\begin{array}{c}\text { Nangarhar } \\
n=86\end{array}$} & \multirow{2}{*}{$\begin{array}{c}\text { Herat } \\
\mathrm{n}=85\end{array}$} \\
\hline I13L & P33L & F57I/L & S58R & T61M & $\mathrm{S} 117 \mathrm{~N} / \mathrm{T}$ & I173L & A383G & A553G & & \\
\hline 1 & $P$ & $\mathrm{~F}$ & S & $\mathrm{T}$ & S & I & A & A & $68(79.1 \%)$ & 79 (92.9\%) \\
\hline I & $P$ & $\mathrm{~F}$ & S & $\mathrm{T}$ & $\underline{N}$ & I & A & A & $10(11.6 \%)$ & $1(1.2 \%)$ \\
\hline I & P & $\mathrm{F}$ & S & $\mathrm{T}$ & SN & । & A & A & 3 (3.5\%) & $3(3.5 \%)$ \\
\hline 1 & P & $\mathrm{F}$ & $\underline{\mathrm{R}}$ & $\mathrm{T}$ & $\underline{N}$ & I & A & A & $2(2.3 \%)$ & $1(1.2 \%)$ \\
\hline I & P & $\mathrm{F}$ & $S \underline{S}$ & $\mathrm{~T}$ & S & I & A & A & $3(3.5 \%)$ & - \\
\hline \multirow[t]{5}{*}{1} & $\mathrm{P}$ & $\mathrm{F}$ & $\underline{\mathrm{R}}$ & $\mathrm{T}$ & $\underline{N}$ & I & $\underline{G}$ & A & - & $1(1.2 \%)$ \\
\hline & & & & & & & & & $\underline{\mathrm{R}}=2.3 \%$ & $\underline{\mathrm{R}}=2.4 \%$ \\
\hline & & & & & & & & & $\mathrm{SR}=3.5 \%$ & - \\
\hline & & & & & & & & & $\underline{\mathrm{N}}=13.9 \%$ & $\underline{\mathrm{N}}=3.5 \%$ \\
\hline & & & & & & & & & $\mathrm{SN}=3.5 \%$ & $\mathrm{SN}=3.5 \%$ \\
\hline
\end{tabular}




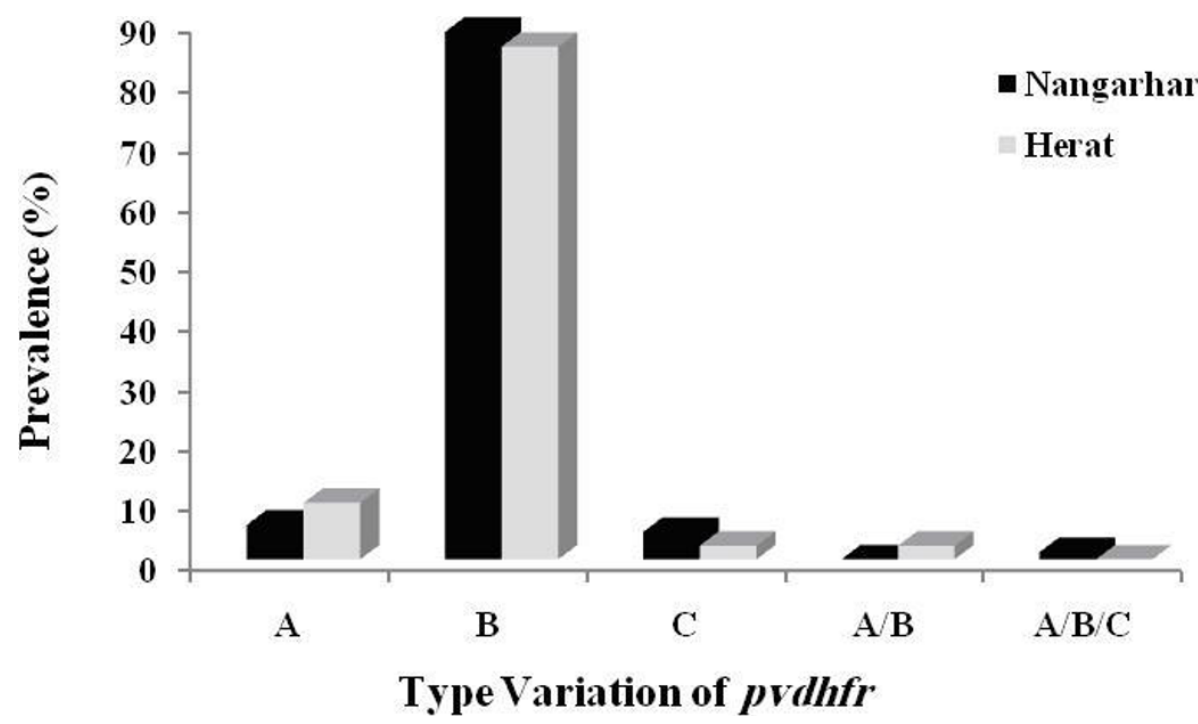

Figure 1 Frequency distribution of pvdhfr repeat region types in wild $\boldsymbol{P}$. vivax isolates from Afghanistan. A: Type A (the largest bp); B: Type B (the middle bp); C: Type C (the smallest bp); ranging between 230 and $280 \mathrm{bp}$. A/B and A/B/C: Mixed genotype infections.

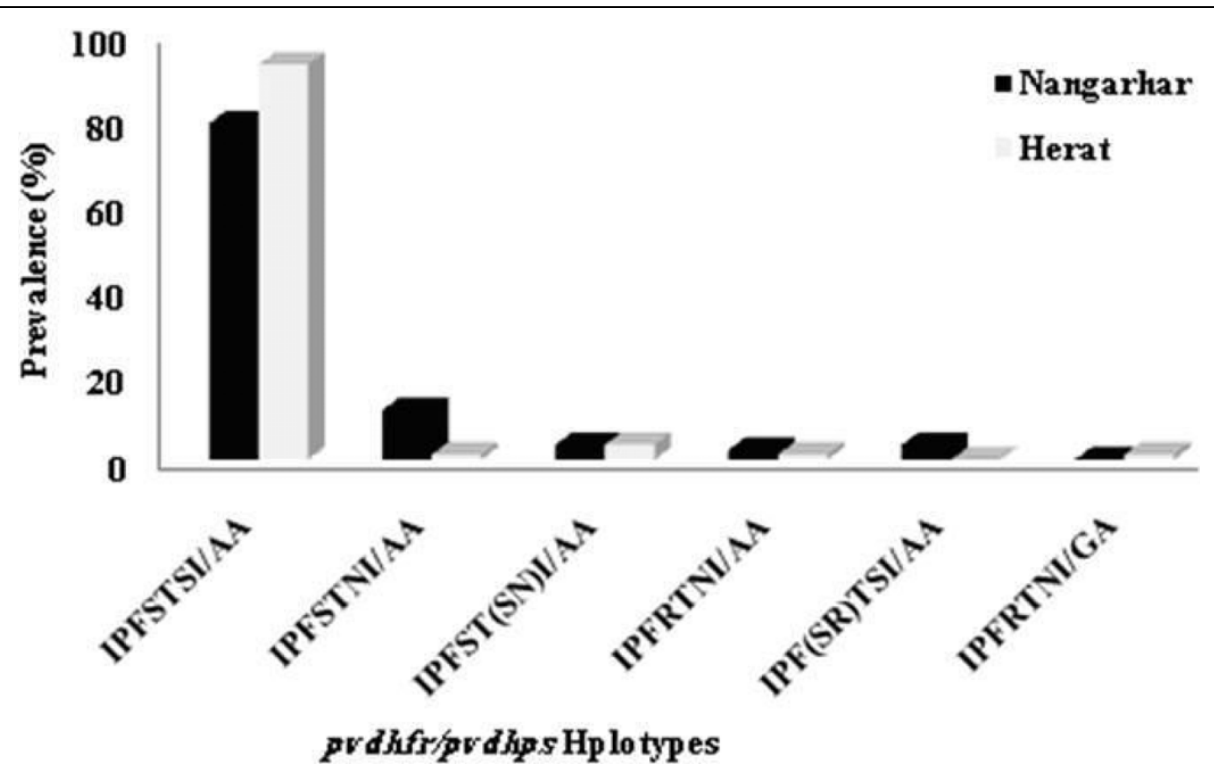

Figure 2 Frequency distribution of the combination pvdhfr/pvdhps haplotypes obtained from 171 isolates collected from Herat province in north-west and Nangarhar province in eastern of Afghanistan. All six haplotypes are indicated as $A$ to $F$ in the Figure. Mutated amino acids are boldfaced. A) $I_{13} P_{33} F_{57} S_{58} T_{61} S_{117} l_{173} / A_{383} A_{553}$ B) $I_{13} P_{33} F_{57} S_{58} T_{61} \underline{N}_{177} l_{173} / A_{383} A_{553}$ C) $I_{13} P_{33} F_{57} S_{58} T_{61} S \underline{N} \underline{N}_{177} l_{173} / A_{383} A_{553}$ D) $\mathrm{I}_{13} \mathrm{P}_{33} \mathrm{~F}_{57} \underline{\mathbf{R}_{58}} \mathrm{~T}_{61} \underline{\mathbf{N}_{117}} \mathrm{I}_{173} / \mathrm{A}_{383} \mathrm{~A}_{553}$ E) $\mathrm{I}_{13} \mathrm{P}_{33} \mathrm{~F}_{57} \underline{\mathbf{R}}_{58} \mathrm{~T}_{61} \mathrm{~S}_{117} \mathrm{I}_{173} / \mathrm{A}_{383} \mathrm{~A}_{553}$ F) $\mathrm{I}_{13} \mathrm{P}_{33} \mathrm{~F}_{57} \underline{\mathbf{R}}_{58} \mathrm{~T}_{61} \underline{\mathbf{N}_{117}} \mathrm{I}_{173} \underline{\mathbf{G}}_{383} \mathrm{~A}_{553}$.

identified at high proportion in Afghan P. vivax isolates and $\quad \mathrm{I}_{13} \mathrm{P}_{33} \mathrm{~F}_{57} \underline{\mathbf{R}}_{58} \mathrm{~T}_{61} \underline{\mathbf{N}}_{117} \mathrm{I}_{173} / \mathrm{A}_{383} \mathrm{~A}_{553}$ and $\mathrm{I}_{13} \mathrm{P}_{33} \mathrm{~S}_{57} \underline{\mathbf{R}}_{58} \mathrm{~T}_{61} \underline{\mathbf{N}}_{117} \mathrm{I}_{173} / \underline{\mathbf{G}}_{383} \mathrm{~A}_{553}$ mutant haplotypes were B type (Table 4).

The most common mutant haplotype is $58 \mathrm{R} / 117 \mathrm{~N}$ of $p v d h f r$ reported from other areas including Iran [21], Pakistan [22], Thailand [23], India [24], Philippines, Vietnam, East Timor, PNG, Vanuatu and Vietnam [25],
Colombia [15], Myanmar [26] and Madagascar [16], but not from Azerbaijan and Turkey [27].

So far, quadruple mutant alleles of $p v d h f r$ that are associated with SP treatment failure were reported from Myanmar [26], India [24], PNG, Vanuatu [25], and Thailand [23] but not from other geographic areas (Additional file 1). Double (383G/553G) and triple 
Table 4 Association between mutations and tandem repeat region type of pvdhfr gene in $P$. vivax isolates from Afghanistan.

\begin{tabular}{|c|c|c|c|c|c|c|c|c|c|c|c|}
\hline \multirow[t]{2}{*}{ Repeat region type } & \multicolumn{7}{|c|}{ pvdhfr } & \multicolumn{2}{|c|}{ pvdhps } & \multirow{2}{*}{$\begin{array}{c}\text { Nangarhar } \\
\mathrm{n}=\mathbf{8 6}\end{array}$} & \multirow{2}{*}{$\begin{array}{l}\text { Herat } \\
\mathrm{n}=85\end{array}$} \\
\hline & I13L & P33L & F57I/L & S58R & T61M & $\mathrm{S} 117 \mathrm{~N} / \mathrm{T}$ & I173L & A383G & A553G & & \\
\hline \multirow[t]{2}{*}{ A } & I & $P$ & $\mathrm{~F}$ & S & T & $\underline{N}$ & 1 & A & A & $2(2.3 \%)$ & - \\
\hline & 1 & $P$ & $\mathrm{~F}$ & S & $\mathrm{T}$ & S & 1 & A & A & $3(3.5 \%)$ & $8(9.4 \%)$ \\
\hline \multirow[t]{6}{*}{ B } & I & $P$ & $\mathrm{~F}$ & $\underline{\mathrm{R}}$ & $T$ & $\underline{N}$ & 1 & A & A & $2(2.3 \%)$ & $1(1.2 \%)$ \\
\hline & । & $P$ & $\mathrm{~F}$ & S & $\mathrm{T}$ & $\underline{N}$ & 1 & A & A & $8(9.3 \%)$ & $1(1.2 \%)$ \\
\hline & I & P & $\mathrm{F}$ & $S$ & $\mathrm{~T}$ & S & 1 & A & A & $61(71 \%)$ & 67 (78.8\%) \\
\hline & 1 & P & $\mathrm{F}$ & $\underline{S R}$ & T & $\mathrm{S}$ & 1 & A & A & $3(3.5 \%)$ & - \\
\hline & 1 & P & $\mathrm{F}$ & $S$ & T & SN & 1 & A & A & $2(2.3 \%)$ & $3(3.6 \%)$ \\
\hline & 1 & $P$ & $\mathrm{~F}$ & S & $\mathrm{T}$ & $\underline{N}$ & 1 & $\underline{G}$ & A & - & $1(1.2 \%)$ \\
\hline $\mathrm{C}$ & 1 & $P$ & $\mathrm{~F}$ & S & $T$ & $S$ & 1 & A & A & $4(4.6 \%)$ & $2(2.3 \%)$ \\
\hline$A / B$ & 1 & $\mathrm{P}$ & $\mathrm{F}$ & $S$ & $\mathrm{~T}$ & $S$ & 1 & A & A & - & $2(2.3 \%)$ \\
\hline$A / B / C$ & I & P & F & S & T & SN & I & A & $A$ & $1(1.2 \%)$ & - \\
\hline
\end{tabular}

(382A/383G/553G) mutant alleles of pvdhps were only reported from Thailand [23] (Additional file 1).

\section{Discussion}

Efforts toward controlling malaria are greatly challenged by the increasing spread of anti-malarial drug resistance and also the use of ineffective anti-malarial drugs. Therefore, there is a need for monitoring anti-malarial drug efficacy and drug resistance in global malaria endemic regions. In the present study, for the first time, the prevalence of mutations in the SP resistance-associated genes, dhfr and dhps was determined in 171 blood samples infected with $P$. vivax collected from two malaria endemic areas of Afghanistan where both CQ and SP were used for treatment. Vivax infections are not often treated with SP; therefore, P. vivax isolates are exposed to SP because mixed infections are present in these regions and are often mis-diagnosed [18].

Afghanistan is a country in south-central Asia that bordered to the west with Iran and to the east and south with Pakistan. Due to war, population displacements and movements across the borders have also occurred and this might contribute to the spread of disease and also parasite resistance to anti-malarial drugs to neighbouring countries. Although there is no in vivo evidence of $P$. vivax resistance to $C Q$ in Afghanistan, an in vivo work in Iran in 2005 [28] showed that parasite clearance time increased when compared to 2001 in Sistan and Baluchistan province. This indicates that it could be an early sign of reduced susceptibility of the $P$. vivax populations to $C Q$ in these regions. Therefore, an effective alternative drug against $P$. vivax resistance to CQ might be needed in near future.

In the present investigation, a limited polymorphism in $p v d h f r$ and $p v d h p s$ genes has been detected that was in contrast with earlier studies in Myanmar [26], PNG, Vanuatu [25], and Thailand [23]. In total, six distinct haplotypes of $p v d h f r$ were detected among Afghan isolates. The wild-type $d h f r / d h p s$ haplotype is present at high proportion in $P$. vivax parasite populations from both study areas in Afghanistan, which was similar to that of obtained from malaria endemic regions in Iran [21] and Pakistan [22]. The single mutant $\mathrm{I}_{13} \mathrm{P}_{33} \mathrm{~F}_{57} \mathrm{~S}_{58} \mathrm{~T}_{61} \mathbf{N}_{117} \mathrm{I}_{173 /} \mathrm{A}_{383} \mathrm{~A}_{553}$ (6.4\%) was the second frequent haplotype in Afghan $P$. vivax isolates; however, double mutant $\mathrm{I}_{13} \mathrm{P}_{33} \mathrm{~F}_{57} \underline{\mathbf{R}}_{58} \mathrm{~T}_{61} \mathbf{N}_{117} \mathrm{I}_{173 /} \mathrm{A}_{383} \mathrm{~A}_{553}$ was the second frequent haplotype in Iranian (9.5\%) and Pakistani (16.1\%) isolates $[21,22]$. The explanation for low prevalence of $\mathrm{I}_{13} \mathrm{P}_{33} \mathrm{~F}_{57} \underline{\mathbf{R}}_{58} \mathrm{~T}_{61} \underline{\mathbf{N}}_{117} \mathrm{I}_{173} / \mathrm{A}_{383} \mathrm{~A}_{553}$ haplotype (1.7\%) among Afghan isolates may be due to the recent usage of SP as the first-line anti-malarial treatment in these areas, as different studies revealed that wild-type $p v d h f r$ has been found more commonly in areas with limited use of SP $[8,10,13,14]$. Moreover, the frequency distribution of $p v d h f r$ mutant haplotypes was significantly higher in the Nangarhar (20.9\%) than Herat province (7\%). This might be also due to gene flow of SP resistance in $P$. vivax populations in a consequence of human migration across border between Pakistan and Afghanistan in Nangarhar province.

Based on size polymorphism of $p v d h f r$ gene at repeat region, among Afghan isolates, type B was identified at high proportion in both study areas similar to the findings from its neighbouring country, Iran [21]. The present investigation also showed the association between mutant haplotypes and type B in both study areas; however final conclusion for such association needs further study in global vivax malaria endemic region. In addition, mixed genotype infections, types $\mathrm{A} / \mathrm{B}$ and $\mathrm{A} / \mathrm{B} / \mathrm{C}$ 
were detected in Herat and Nangarhar isolates, respectively; however, the only mixed type detected in Iranian malaria settings was $\mathrm{B} / \mathrm{C}$ genotype [21].

The $58 \mathrm{R}$ and $117 \mathrm{~N}$ were found in $4.1 \%$ and $12.3 \%$ of all examined isolates, respectively and in combination with each other $(58 \mathrm{R} / 117 \mathrm{~N})$ in $2.3 \%$. Surprisingly, $117 \mathrm{~N}$ was detected at high frequency among isolates collected from Turkey (36\%), Azerbaijan (71\%) and Pakistan (93.5\%) [22,27].

Mutations at codons 58 and 117 in pvdhfr gene are also considered to be equivalent to mutations at residues 59 and 108 in $p f d h f r$, respectively that are known to be associated with pyrimethamine resistance. In fact, double mutations at codons $58 \mathrm{R}$ and $117 \mathrm{~N}$ in $p v d h f r$ may arise first under drug pressure and move toward the development of resistance to SP [8]. As a result, these two mutations were detected in $P$. vivax populations in Iran [21], Pakistan [22] and Afghanistan [present study] three years after using SP-artesunate as firstline treatment of uncomplicated P. falciparum in these regions. In the present study, quadruple mutants were not detected among examined isolates; however, quadruple mutant alleles of pvdhfr at codons 57, 58, 61 and 117 predominated in clinical isolates in Thailand, where $P$. falciparum showed multi-drug resistance [23], Myanmar, Indonesia and India $[8,10,26,29,30]$. The difference in the prevalence of mutant $p v d h f r$ alleles reflects the selection pressure exerted by usage of the antifolate drug in these countries.

The work carried out by Tahar and colleagues [31] showed that the $58 \mathrm{R} / 117 \mathrm{~N}$ mutant had a lower affinity for pyrimethamine and cycloguanil than did the wildtype enzyme. Different studies also showed that in areas where antifolate has been intensively used, such as Thailand and Indonesian Papua, haplotypes that carry more than two mutations of $d h f r$ are more prevalent and surely are resistance to pyrimethamine $[8,10,14,27,32]$. Patients whose parasites carried the $57 \mathrm{~L} / 61 \mathrm{M} / 117 \mathrm{~T} /$ $173 F$ allele were more likely to fail SP treatment $[14,29]$. In addition, treatment failure was more frequently associated with multiple mutations in $p v d h f r$ and pvdhps [20] and also when the parasite carries mutant alleles of both genes, clinical effectiveness is compromised [33-35]. In the present study, the most common haplotypes of $p v d h f r$ were wild-type and double mutant (58R and $117 \mathrm{~N}$ ), quadruple mutant were not detected among examined isolates. This suggests that a DHFR inhibitor could be effective in treatment against the erythrocytic stages of vivax malaria. In contrast, molecular analysis of $p v d h f r$ among Indian field isolates showed haplotypes from wild-type to quadruple mutant genotype. These haplotypes may be come from Indian subcontinent to this area as gene flow of anti-malarial drug resistance in malaria parasites might be often a consequence of human migration rather than the emergence of new mutations. Moreover, the results support the concept of east to west reduction in SP pressure and this might be reflected in the presence of different mutations in the pvdhfr gene.

\section{Conclusions}

The present molecular data shows a limited polymorphism in $p v d h f r$ from Afghan isolates and it provides important basic information for monitoring SP resistance in Afghanistan. The present study shows high prevalence of wild-type and low frequency of single mutated $p v d h f r$ alleles among Afghan isolates. However, the continuous SP pressure in Afghanistan might progress mutations in the dhfr gene in both $P$. vivax and $P$. falciparum species, which may finally lead to a complete SP resistance in this region. Therefore, continuous surveillance of $P$. vivax and $P$. falciparum molecular markers are needed to monitor the development of resistance to SP. Moreover, such information is necessary for guiding malaria control measures in the frame of Roll Back Malaria strategies for eliminating of malaria in this region.

Additional file 1: Frequency distribution of different haplotypes of pvdhfr and pvdhps in different geographic areas.

Click here for file

[ http://www.biomedcentral.com/content/supplementary/1475-2875-9-75S1.DOC]

\section{Acknowledgements}

We acknowledge the co-operation of Dr. Tajwar, Dr. Mohammad Younus from Afghanistan. We are grateful for the hospitality and generous collaboration of all lab technicians from Afghanistan for their logistic support in collecting blood samples, for microscopy-based malaria diagnosis and reviewing malaria slides in the field. We are indebted to the patients and their families for their willingness to participate in this study. This study was partially supported by grants from Iranian Ministry of Health and Medical Education, and Institut Pasteur of Iran.

\section{Author details}

${ }^{1}$ Malaria and Vector Research Group (MVRG), Biotechnology Research Center, Institut Pasteur of Iran, Pasteur Avenue, P.O. BOX 1316943551, Tehran, Iran. ${ }^{2}$ National Programme Manager for Malaria Control, Ministry of Health and Medical Education, Tehran, Iran. ${ }^{3}$ National Malaria and Leishmaniasis Control Programme Manager, Ministry of Public Health, Kabul, Afghanistan. ${ }^{4}$ Medical Officer, Malaria and Leishmaniasis, WHO Office, Kabul, Afghanistan. ${ }^{5}$ Roll Back Malaria, WHO/EMRO, Cairo, Egypt.

\section{Authors' contributions}

SZ designed and supervised the study, analysed the data and wrote the manuscript. MA and FGH contributed in the laboratory work and helped with analysis of the data. AR, NS, WB, and HA participated in field work, study coordination and preliminary analysis. NDD helped with analysis of the data and also helped with the writing of the manuscript. All authors read and approved the final manuscript. 


\section{Competing interests}

The authors declare that they have no competing interests.

Received: 3 January 2010 Accepted: 14 March 2010

Published: 14 March 2010

\section{References}

1. Mendis K, Sina BJ, Marchesini P, Carter R: The neglected burden of Plasmodium vivax malaria. Am J Trop Med Hyg 2001, 64(1-2 Suppl):97-106.

2. Barat LM, Bloland PB: Drug resistance among malaria and other parasites. Infect Dis Clin North Am 1997, 11:969-987.

3. Nomura T, Carlton JM, Baird JK, Del Portillo HA, Fryauff DJ, Rathore D, Fidock DA, Su X, Collins WE, McCutchan TF, Wootton JC, Wellems TE: Evidence for different mechanisms of chloroquine resistance in 2 Plasmodium species that cause human malaria. J Infect Dis 2001, 183:1653-1661

4. Tjitra E, Anstey NM, Sugiarto P, Warikar N, Kenangalem E, Karyana M, Lampah DA, Price RN: Multidrug-resistant Plasmodium vivax Associated with severe and fatal malaria: A prospective study in Papua, Indonesia. PLoS Med 2008, 5:e128.

5. Barcus MJ, Basri H, Picarima H, Manyakori C, Sekartuti, Elyazar I, Bangs MJ, Maguire JD, Baird JK: Demographic risk factors for severe and fatal vivax and falciparum malaria among hospital admissions in northeastern Indonesian Papua. Am J Trop Med Hyg 2007, 77:984-991.

6. Bonilla JA, Validum L, Cummings R, Palmer CJ: Genetic diversity of Plasmodium vivax pvcsp and pvmsp1 in Guyana, South America. Am J Trop Med Hyg 2006, 75:830-835.

7. Gregson A, Plowe CV: Mechanisms of resistance of malaria parasites to antifolates. Pharmacol Rev 2005, 57:117-145.

8. Imwong M, Pukrittayakamee S, Rénia L, Letourneur F, Charlieu JP, Leartsakulpanich U, Looareesuwan S, White NJ, Snounou G: Novel point mutations in the dihydrofolate reductase gene of Plasmodium vivax: evidence for sequential selection by drug pressure. Antimicrob Agents Chemother 2003, 47:1514-1521.

9. Foote SJ, Cowman AF: The mode of action and the mechanism of resistance to antimalarial drugs. Acta Trop 1994, 56:157-171.

10. Imwong M, Pukrittakayamee S, Looareesuwan S, Pasvol G, Poirreiz J, White NJ, Snounou G: Association of genetic mutations in Plasmodium vivax $\mathrm{dhfr}$ with resistance to sulfadoxine-pyrimethamine: geographical and clinical correlates. Antimicrob Agents Chemother 2001, 45:3122-3127.

11. Triglia T, Menting JG, Wilson C, Cowman AF: Mutations in dihydropteroate synthase are responsible for sulfone and sulfonamide resistance in Plasmodium falciparum. Proc Natl Acad Sci USA 1997, 94:13944-13949.

12. Plowe CV, Cortese JF, Djimde A, Nwanyanwu OC, Watkins WM, Winstanley PA, Estrada-Franco JG, Mollinedo RE, Avila JC, Cespedes JL, Carter D, Doumbo OK: Mutations in Plasmodium falciparum dihydrofolate reductase and dihydropteroate synthase and epidemiologic patterns of pyrimethamine-sulfadoxine use and resistance. J Infect Dis 1997, 176:1590-1596.

13. Tjitra E, Baker J, Suprianto S, Cheng Q, Anstey NM: Therapeutic efficacies of artesunate-sulfadoxine-pyrimethamine and chloroquine-sulfadoxinepyrimethamine in vivax malaria pilot studies: relationship to Plasmodium vivax dhfr mutations. Antimicrob Agents Chemother 2002, 46:3947-3953.

14. de Pécoulas PE, Tahar R, Ouatas T, Mazabraud A, Basco LK: Sequence variations in the Plasmodium vivax dihydrofolate reductase-thymidylate synthase gene and their relationship with pyrimethamine resistance. Mol Biochem Parasitol 1998, 92:265-273.

15. Hawkins VN, Joshi H, Rungsihirunrat $\mathrm{K}$, Na-Bangchang K, Sibley $\mathrm{CH}$ : Antifolates can have a role in the treatment of Plasmodium vivax. Trends Parasitol 2007, 23:213-222.

16. Barnadas C, Tichit M, Bouchier C, Ratsimbasoa A, Randrianasolo L, Raherinjafy R, Jahevitra M, Picot S, Ménard D: Plasmodium vivax dhfr and dhps mutations in isolates from Madagascar and therapeutic response to sulphadoxine-pyrimethamine. Malar J 2008, 7:35.

17. Ministry of Health Afghanistan. [http://htpp://www.emro.who.int/ afghanistan/pdf/nmsp_08_013].

18. Zakeri S, Kakar Q, Ghasemi F, Raeisi A, Butt W, Safi N, Afsharpad M, Memon MS, Gholizadeh S, Salehi M, Atta H, Zamani G, Djadid ND: Detection of high prevalence of mixed Plasmodium falciparum and $P$. vivax infections by nested-PCR in Pakistan and Iran but not in Afghanistan. Indian Journal of Medical Research 2010.
19. Snounou G, Viriyakosol S, Zhu XP, Jarra W, Pinheiro L, do Rosario VE, Thaithong S, Brown KN: High sensitivity of detection of human malaria parasites by the use of nested polymerase chain reaction. Mol Biochem Parasitol 1993, 61:315-320.

20. Imwong M, Pukrittayakamee S, Cheng Q, Moore C, Looareesuwan S, Snounou G, White NJ, Day NP: Limited polymorphism in the dihydropteroate synthetase gene (dhps) of Plasmodium vivax isolates from Thailand. Antimicrob Agents Chemother 2005, 49:4393-4395.

21. Zakeri S, Motmaen SR, Afsharpad M, Djadid ND: Molecular characterization of antifolates resistance-associated genes, (dhfr and dhps) in Plasmodium vivax isolates from the Middle East. Malar J 2009, 8:20.

22. Khatoon L, Baliraine FN, Bonizzoni M, Malik SA, Yan G: Prevalence of antimalarial drug resistance mutations in Plasmodium vivax and $P$. falciparum from a malaria-endemic area of Pakistan. Am J Trop Med Hyg 2009, 81:525-528.

23. Rungsihirunrat K, Na-Bangchang K, Hawkins VN, Mungthin M, Sibley CH: Sensitivity to antifolates and genetic analysis of Plasmodium vivax isolates from Thailand. Am J Trop Med Hyg 2007, 76:1057-1065.

24. Kaur S, Prajapati SK, Kalyanaraman K, Mohmmed A, Joshi H, Chauhan VS: Plasmodium vivax dihydrofolate reductase point mutations from the Indian subcontinent. Acta Trop 2006, 97:174-180.

25. Auliff A, Wilson DW, Russell B, Gao Q, Chen N, Anh le N, Maguire J, Bell D, O'Neil MT, Cheng Q: Amino acid mutations in Plasmodium vivax DHFR and DHPS from several geographical regions and susceptibility to antifolate drugs. Am J Trop Med Hyg 2006, 75:617-621.

26. Na BK, Lee HW, Moon SU, In TS, Lin K, Maung M, Chung GT, Lee JK, Kim TS, Kong Y: Genetic variations of the dihydrofolate reductase gene of Plasmodium vivax in Mandalay Division, Myanmar. Parasitol Res 2005, 96:321-325.

27. Brega S, de Monbrison F, Severini C, Udomsangpetch R, Sutanto I, Ruckert $P$, Peyron F, Picot $S$ : Real-time PCR for dihydrofolate reductase gene single-nucleotide polymorphisms in Plasmodium vivax isolates. Antimicrob Agents Chemother 2004, 48:2581-2587.

28. Nateghpour M, Sayedzadeh SA, Edrissian GhH, Raeisi A, Jahantigh A, Motevalli-Haghi A, Mohseni Gh, Rahimi A: Evaluation of sensitivity of Plasmodium vivax to chloroquine. Iranian J Publ Health 2007, 36:60-63.

29. Hastings MD, Porter KM, Maguire JD, Susanti I, Kania W, Bangs MJ, Sibley CH, Baird JK: Dihydrofolate reductase mutations in Plasmodium vivax from Indonesia and therapeutic response to sulfadoxine plus pyrimethamine. J Infect Dis 2004, 189:744-750.

30. Prajapati SK, Joshi H, Valecha N, Reetha AM, Eapen A, Kumar A, Das MK, Yadav RS, Rizvi MA, Dash AP: Allelic polymorphism in the Plasmodium vivax dihydrofolate reductase gene among Indian field isolates. Clin Microbiol Infect 2007, 13:331-334.

31. Tahar R, de Pécoulas PE, Basco LK, Chiadmi M, Mazabraud A: Kinetic properties of dihydrofolate reductase from wild-type and mutant Plasmodium vivax expressed in Escherichia coli. Mol Biochem Parasitol 2001, 113:241-249

32. Hastings MD, Sibley CH: Pyrimethamine and WR99210 exert opposing selection on dihydrofolate reductase from Plasmodium vivax. Proc Natl Acad Sci USA 2002, 99:13137-13141.

33. Kublin JG, Dzinjalamala FK, Kamwendo DD, Malkin EM, Cortese JF, Martino LM, Mukadam RA, Rogerson SJ, Lescano AG, Molyneux ME, Winstanley PA, Chimpeni P, Taylor TE, Plowe CV: Molecular markers for failure of sulfadoxine-pyrimethamine and chlorproguanil-dapsone treatment of Plasmodium falciparum malaria. J Infect Dis 2002, 185:380-388

34. Nzila AM, Mberu EK, Sulo J, Dayo H, Winstanley PA, Sibley CH, Watkins WM: Towards an understanding of the mechanism of pyrimethaminesulfadoxine resistance in Plasmodium falciparum: genotyping of dihydrofolate reductase and dihydropteroate synthase of Kenyan parasites. Antimicrob Agents Chemother 2000, 44:991-996.

35. Mutabingwa T, Nzila A, Mberu E, Nduati E, Winstanley P, Hills E, Watkins W: Chlorproguanil-dapsone for treatment of drug-resistant falciparum malaria in Tanzania. Lancet 2001, 358:1218-1223.

doi:10.1186/1475-2875-9-75

Cite this article as: Zakeri et al.: Molecular surveillance of Plasmodium vivax dhfr and dhps mutations in isolates from Afghanistan. Malaria Journal 2010 9:75. 